P-ISSN : 1412-6141

E-ISSN : $2548-7744$

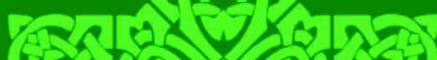
जी $1 \mathrm{a}-1 \mathrm{a})$ यंज जिएक

(4) 1.

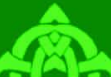

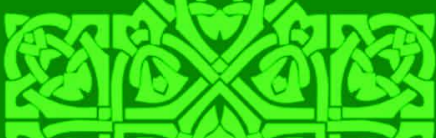
पै $\rightarrow$ जि
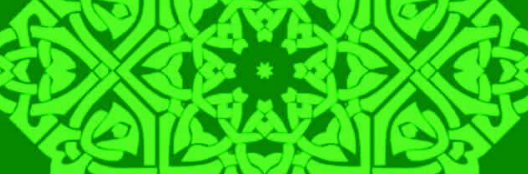

$2=$

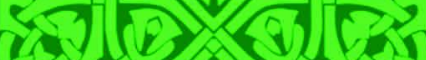

zela $M$ -

ind

(y)

(1)

a.

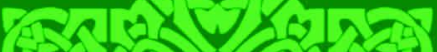

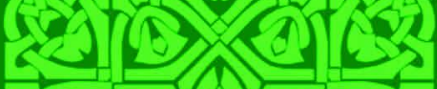

th 1 री
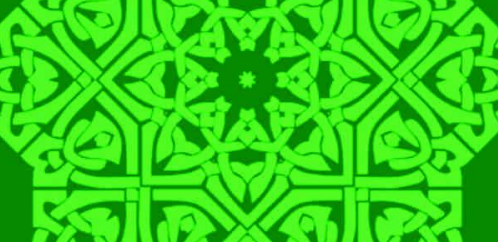

(1) 1001

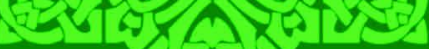

into

(2)

(1)

T.

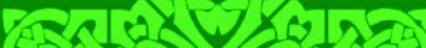

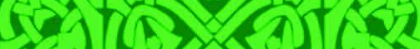

2

$x=1,12$
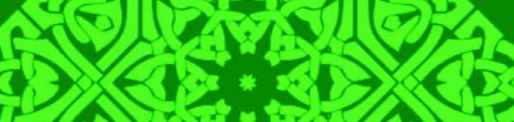

पet (2:

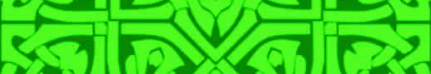

ind

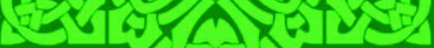

105

(i)

Vol 19. No 1/2019
Rabiatul Adawiah, Srimusdikawati Contextualization And Entextualization Mandarese Patriotism In Kalindaqdaq Pettomuaneang Performance

Mahmuddin دراسة لغوية عن المجاز و علاقته في فهم التعاليم الدينية Andi Miswar Semantic Analysis On The Use Of Hijab And Jilbab Based On Quran Perspective

Aksa Muhammad Nawawi أغر اض الاستفهام بـ "هل" فى الذكر الحكيم

Syamzan Syukur Endogamy Marriage Tradition Of Sayyid Community In Sidenre Village, Binamu District, Jeneponto Regency 


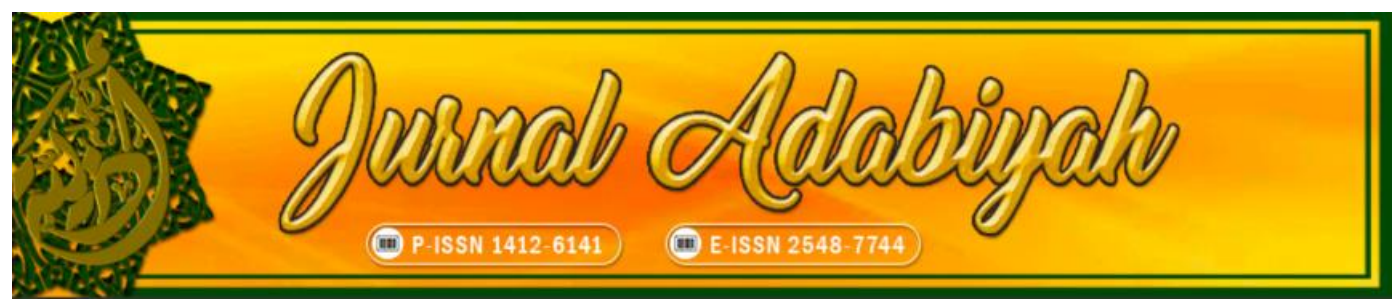

Thema: Humanities

\section{VOLUME 19 NO. 1 JUNI 2019}

\section{EDITOR-IN-CHIEF}

Barsihannor, Alauddin State Islamic University, Indonesia

INTERNATIONAL EDITORIAL BOARD

Nuri Emmiyati, Alauddin State Islamic University, Indonesia

Minako Sakai, Australian National University (ANU), Australia

Abd Rauf Muhammad Amin, Fakulti Syariah Kupu SB Brunei Darussalam, Brunei Darussalam Muhammad Widus Sempo, Universiti Sains Islam Malaysia, Malaysia

Salih Yousif Sharaf Mohamed, Al-Gazera University, Sudan Aishah Waenaha Waemamah, Academy of Islamic and Arabic Studies Princess of Naradhiwas University - Thailand, Thailand

\section{EXECUTIVE EDITOR}

Umar Thamrin, Universitas Islam Negeri Alauddin, Indonesia

\section{MANAGING EDITOR}

Zaenal Abidin, Universitas Islam Negeri Alauddin

\section{EDITORS}

Rosmah Tami, Alauddin State Islamic University, Indonesia Haniah Haniah, Alauddin State Islamic University, Indonesia Nasrum Nasrum, Alauddin State Islamic University, Indonesia Awaluddin Syamsu, Universitas Muslim Indonesia

Ahmadi Usman, UIN Syarif Hidayatullah Jakarta, Indonesia Baso Pallawagau, IAIN Parepare, Indonesia Muhammad Azwar, Universitas Islam Negeri Syarif Hidayatullah Jakarta, Indonesia

Muh. Saleh Syamsuri, Alauddin State Islamic University, Indonesia

Andi Satrianingsih, Muhammadiyah University, Indonesia

Syahruni - Junaid, Alauddin State Islamic University, Indonesia

Rabiatul Adawiah, Majene Islamic State College, West Sulawesi, Indonesia, Indonesia

Chusnul Chatimah Asmad, Universitas Islam Negeri Alauddin, Indonesia

Nur Arifin, Universitas Islam Negeri Alauddin, Indonesia

\section{IT SUPPORT}

Taufiq Mathar, Alauddin State Islamic University, Indonesia

\section{LANGUAGE ADVISOR}

Kustiwan Syarief, Alauddin State Islamic University, Indonesia Muh. Saleh Syamsuri, Alauddin State Islamic University, Indonesia

\section{COVER DESIGNER}

Nur Arifin 


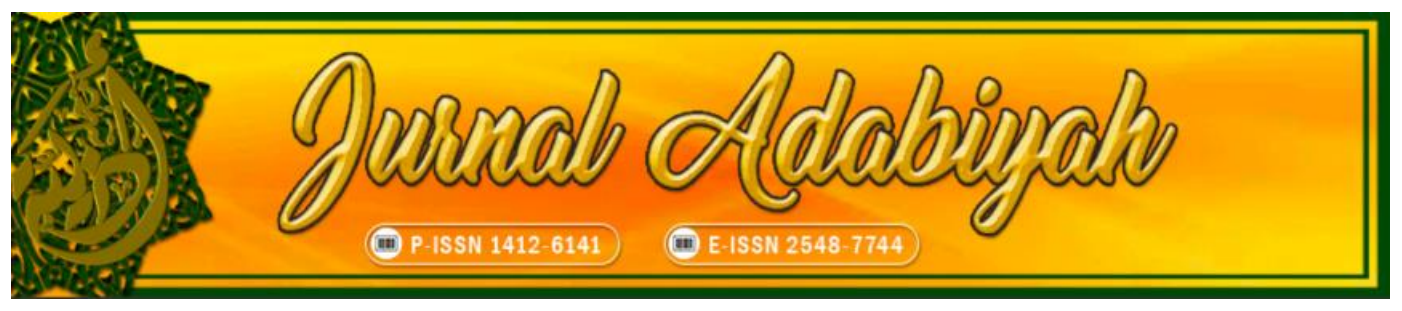

\section{Jurnal Adabiyah:}

This journal receives a national accreditation from Ministry of Research, Technology, and Higher Education Republic of Indonesia, Nomor 10/E/KPT/2019 on April 4, 2019 with the SINTA score: S2.

The Journal has been published by the Faculty of Adab and Humanity of Alauddin State Islamic University, Makassar, since 1997 and has been online since 2016 with the main themes on Humanities and Islamic Studies with the emphasis on interdisciplinary and intertextuality approach.

This journal are published twice a year, on June and December. The themes related to Islamic Studies are textual studies, scriptural traditions, Islamic law, and theology; and those related to Humanities are language, literature, history, and culture.

The journal of Humanities and Islamic Studies will provide the online collection of articles from 1997 up to now. The most updated information can be found on the website. 


\section{Table of Contents}

Rabiatul Adawiah, Srimusdikawati

Contextualization And Entextualization Mandarese Patriotism In

Kalindaqdaq Pettomuaneang Performance

Mahmuddin

در اسة لغوية عن المجاز و علاقته في فهم التعاليم الدينية

Andi Miswar

Semantic Analysis On The Use Of Hijab And Jilbab Based On Qur'an Perspective

Aksa Muhammad Nawawi

أغر اض الاستفهام بـ "هل" فى الذكر الحكيم

Syamzan Syukur, Arbianti.

Endogamy Marriage Tradition Of Sayyid Community In Sidenre Village,

Binamu District, Jeneponto Regency 


\title{
CONTEXTUALIZATION AND ENTEXTUALIZATION MANDARESE PATRIOTISM IN KALINDAQDAQ PETTOMUANEANG PERFORMANCE
}

\author{
Rabiatul Adawiah \\ Sekolah Tinggi Agama Islam Negeri Majene \\ rabiatul.adawiah@stainmajene.ac.id \\ Srimusdikawati \\ SMA Negeri 1 Matakali, Sulbar \\ srimusdikawati2015budayamandar@gmail.com
}

\begin{abstract}
Kalindaqdaq is one literary work of Mandarese, the majority ethnic in West Sulawesi. It is categorized as an old poem, and nowadays Kalindaqdaq is only shown in a few cultural events. The objective of this research is to explore Mandarese local wisdom related to patriotism through contextualizing and entextualizing Kalindaqdaq Pettomuaneang. This research used a qualitative method with two approaches; systemic functional and ethnographical approach. The result shows that the emergence of Kalindaqdaq Pettomuaneang was influenced by the political situation. Based on its contextualization, there are three characteristics of an ideal leader. They must have sincerity, consistency, and firmness. Next, intextuality involved some contexts. Texts in manetteq context are decontextualized such as manetteq (weave), lipaq (sarong), bannang pute (white yarn), lango-lango (dye), sureq (motif), and pucca (center of motif), and after that, they are recontextualized in patriotism as its new context. Leadership is seen as the same as weaving process, not only be carefulness, a good leader should be creative. So seeing the success of contextualization and entextualization in Kalindaqdaq Pettomuaneang, it can be concluded that Mandarese is ethnic with high cognitive characteristics. Because of to do contextualization and entextualization, people should have specific competence in language and logic.
\end{abstract}

Keywords: Mandarese; Patriotism; Kalindaqdaq; Contextualization; Entextualization.

\begin{abstract}
Abstrak
Kalindaqdaq merupakan satu karya sastra dari Mandar, suku terbesar di wilayah Sulawesi Barat. Tergolong sebagai puisi lama, kalindaqdaq kini hanya ditampilkan pada beberapa acara adat. Penelitian ini bertujuan untuk mengekplorasi kearifan lokal Mandar terkait dengan nilai patriotism melalui kontekstualisasi dan entekstualisasi Kalindaqdaq Pettomuaneang
\end{abstract}


(Puisi Mandar genre patriotisme). Penelitian ini menggunakan metodologi kualitatif dengan dua pendekatan: sistemik fungsional dan etnografi. Genre kalindaqdaq ini muncul seiring dengan situasi politik masa kerajaan dahulu. Hasil kontekstualisasi teks kalindaqdaq menunjukkan bahwa ada tiga karakter yang harus dimiliki oleh seorang pemimpin; ketulusan, konsistensi, dan ketegasan. Proses entekslualisasi melibatkan beberapa konteks. Teks manetteq (menenun), lipaq (sarung), bannang pute (benang putih), lango-lango (pewarna), sureq (motif sarung), and pucca (inti motif) diambil dari konteks kegiatan menenun sarung sutera, kemudian ditarik ke dalam konteks baru yakni konteks patriotisme untuk menggambarkan karakter seorang pemimpin yang patriot. Proses kepemimpinan dipandang sama dengan proses menenun sarung; tidak hanya penuh kehati-hatian, seorang pemimpin yang baik harus kreatif. Melihat proses kontekstualisasi dan entekstualisasi dalam karya puisi kalindaqdaq, maka dapat disimpulkan bahwa suku Mandar memiliki kemajuan dan kemampuan kognitif yang tinggi dalam bidang bahasa, sastra, dan logika.

Kata Kunci: Mandar; Patriotisme; Kalindaqdaq; Kontekstualisasi; Entekstualisasi

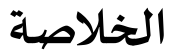

كلندأدأ هو أحد الأعمال الأدبية من قبيلة مندر، وهي أكبر القبر القبائل في

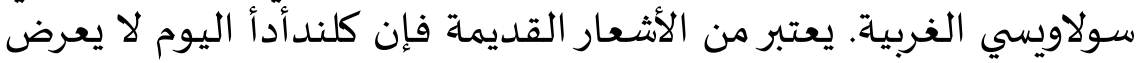

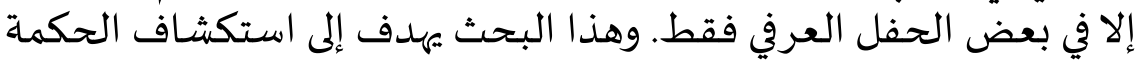

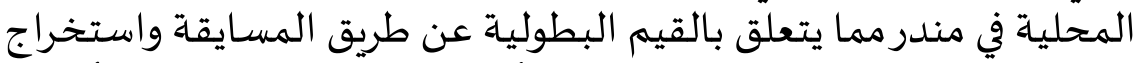

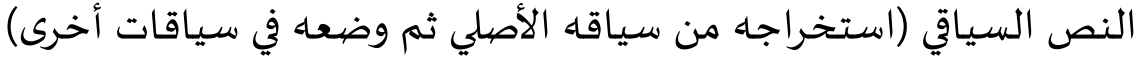

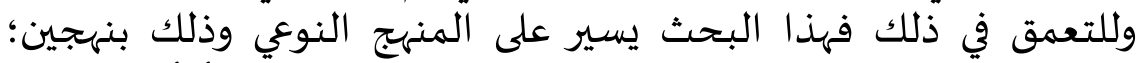

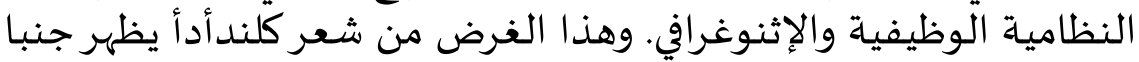

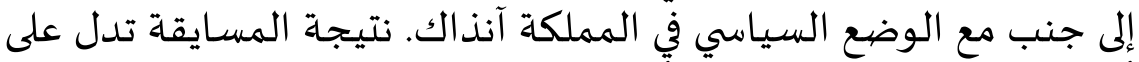

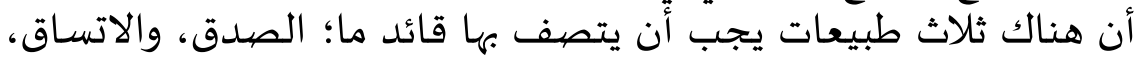

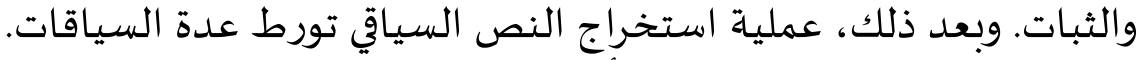

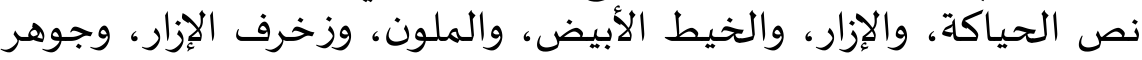

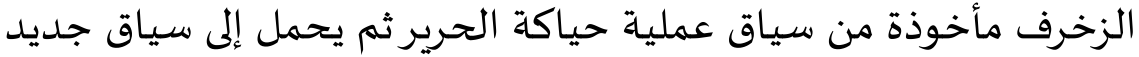

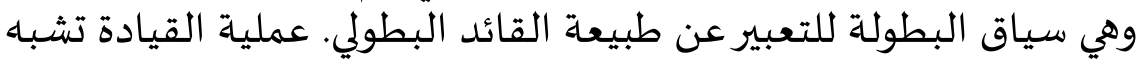

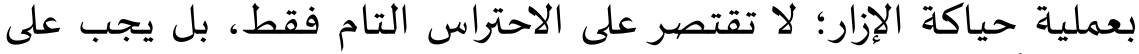

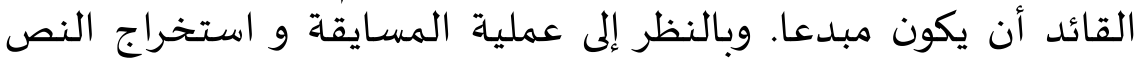

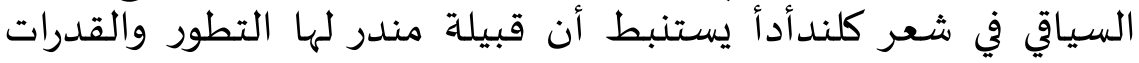

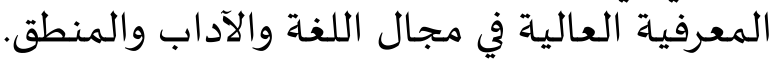




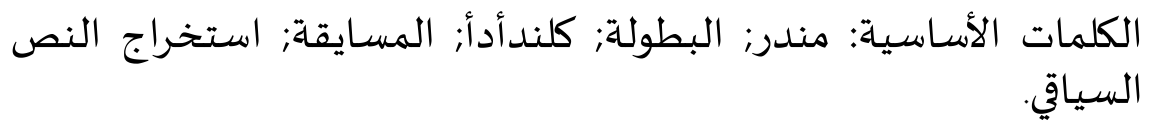

\section{A. Introduction}

Mandarese is one of thousand ethnics in Indonesia. The base of Mandarese mostly is in West Sulawesi, the youngest province in Celebes Island. There are 1.282.180 societies living in this province, and the number of Mandarese is about 49.15\%. ${ }^{1}$ The root of "Mandar" is Manda', and comes from Ulu Salu (montain area in Sulawesi Barat). It means 'strong', similar to the root of "Makassar" namely makassa' and masse'. Allamungang Batu di Luyo, an old epigraph, states that Mandarese was formed by unifying fourteen kingdoms. They shared their habitual, rituals, beliefs, values and other elements of culture with keeping respect each other related to boundary of those kingdoms. ${ }^{2}$

The large number of Mandarese does not stand for its popularity and maintenance. Examining in contrast with other ethnics around it, Mandarese has not been well-known so far. Meanwhile, many people notice easily Torajanese, and Buginese-Makassarese. Tourists from various countries have come to watch dead rituals in Torajanese; and then, Lagaligo script of Buginese-Makassarese has been studied and digitalized in several libraries abroad. It seems irony because Mandarese are not able to make their ethnic being exist in tourism and academic point of view among other ethnics around them, whereas historically and psychologically Mandarese is not different to Torajanese and Buginese-Makassarese. ${ }^{3}$

Conducting ethnography studies could be one solution to maintain the existence of culture. ${ }^{4}$ This approach will show the real situation and update phenomena related to that culture. The result of ethnographical studies can be consideration in decision making, for example to the government, related to that culture. Cristian Pelras in 2006 had published Manusia Bugis; Stanislaus Sandarupa in 2016 has launched Kebudayaan Tallulolona Toraja and; the study of Lagaligo codices has been spread in Europe; while, almost nothing is in Mandarese. Although some experts ${ }^{5}$ have written many works of Mandarese issues, they are only published locally. Moreover, they are not compiled

${ }^{1}$ Badan Pusat Statistika Provinsi Sulawesi Barat, Jumlah Penduduk menurut Kabupaten/Kota, 2010-2015, accessed from http://sulbar.bps.go.id/, on January, $11^{\text {st }} 2017$ at $1 \mathrm{pm}$

${ }^{2}$ Kasitowati, Rarasrum Dyah. Sandeq dan Roppoq, Jurnal Sabda, Vol.6, No.1. (2011)

${ }^{3}$ Mattulada, South Sulwesi, It Etnicity and ay of Life, South Asian Studies Journal, Vol. 20, No.1. (1982)

${ }^{4}$ James P. Sparadley, Doing Participant Observation (USA: 1980)

${ }^{5}$ They are Abdul Muthalib, M. Darwis Hamzah, Abdul Muis Badulu, Idham Chalik Bodi, Suradi Yasil, A.M. Sarbin Sjam, Haji Saharuddin, Abdul Muis Manra, Majid Tanawali Syah Azis, Ridwan Alimuddin, etc. 
well. This situation is the next irony remembering that Mandarese is a prosperous ethnic. There are rich of local wisdoms that actually are potential to be explored by conducting ethnography studies. By doing and publishing the result of cultural studies, that culture actually has been maintained and saved form the death.

One of literary works which is important and interesting to be a research object is Kalindaqdaq. The researchers think that it could be a good start to explore this ethnic. Kalindaqdaq is categorized as old poem, and today it is not performed anytime. In the former time, Mandarese could listen and take pleasure from Kalindaqdaq in some cultural rituals. But nowadays, it is only performed in mappatamma' (a celebrated ceremony after reciting Al-quran completely) and pammacca (traditional self-defense performance). Other rituals such as marriage ceremony including mammanu'-manu' (proposing step) and matanda-jari (enacting step) rarely perform it. That is why many Mandarese do not know how to make and perform Kalindaqdaq; whereas, this literary work actually can be identified as one artifact which contains value and knowledge system of Mandarese. In conclusion, study on Kalindaqdaq means an exploration of Mandarese's value and knowledge systems.

Exploring local wisdom absolutely gives significant advantages. It is expected to be a way of cultural promotion and maintenance. The cultural promotion can take a specific position to invite domestic and international tourist. Then, the cultural maintenance takes position as alarm to Mandarese in common to be aware that they have local wisdom, and it almost disappears. Values, knowledge, beliefs and spirit in local wisdoms surely can be used as resources of solution to solve any social problems. As instance and as the focus of this research, contents of Kalindaqaq Pettomuaneang are investigated in order to gain lessons about the Mandarese patriotism concept. This information is expected to be reference in clearing up the leadership crisis in Mandarese and other areas. This issue became urgent, remembering the crisis of leadership in Indonesia commonly causes the rising corruption, nepotism, and other cases. Exploring and maintaining lessons from Kalindaqdaq Pattommuaneang is expected to be able presenting solution and antidote of those social problems.

To explore well, the researchers determine to observe the contextualization and entextualization process of Kalindaqdaq. It is chosen for two reasons; firstly, the analysis seeing these processes is the most appropriate technique in observing the relation between Kalindaqdaq as text and Mandarese life as context. Moreover, Kalindaqdaq can be seen as one cultural performance which should be explored by examining the nature of language and social situation. Secondly, most previous studies of Kalindaqdaq were conducted as text analysis which did not involve the discourse analysis such as contextualization and entextualization process in their explanation. For example, Nurhayati in 2014 presented paper on National seminar on Language and Literature and showed that there are 6 (six) spirits of patriotism in Kalindaqdaq. ${ }^{6}$ The meaning of those spirits were translated using KBBI (Kamus Besar Bahasa Indonesia), then the author tried to find any Kalindaqdaq text that represented those spirits. Another study was conducted by Suradi Yasil and Muhammad Darwis in 2017. They foccused

${ }^{6}$ Nurhayati, Patriotisme dalam Kalindaqdaq Mandar. Prosiding Seminar Nasional Bahasa dan Sastra. (2014) 
on language style used and how those language styles describe the image of Mandaresse. ${ }^{7}$ Both studies include text-meaning analysis in surface level. The finding and discusion parts did not touch the exploring of Mandaresse context in building up the meaning of words used. It is needed to explore them in order to find the involved and produced contexts, and it's relation to local wisdom in Mandar area.

In conclusion, the researchers believe that this research will be something new in the study of Mandarese literary works. Moreover, nobody has conducted a research of Kalindaqdaq combining local literary studies and discourse analysis.

\section{B. Review of Litarature}

\section{Review of Kalindaqdaq}

Mandarese as a large ethnic in Celebes area, of course, has rich of literary works. One of them is Kalindaqdaq which can be categorized as old poem. Kalindaqdaq is formed by two words; ' $k a l i$ ' means discover and 'daqdaq' means heart (Bodi 2013) ${ }^{8}$. So, the etymological definition of Kalindaqdaq is discovering feeling and thought that is expressed in beautiful and artistic ways.

Similar to other oral literary works, there is not clear explanation about Kalindaqdaq history including who firstly creates it; when and where it is performed early; and why it could be here today. And because Kalindaqdaq is only spread orally, it could be assumed that Mandarese had not had a good writing habitual at the first of Kalindaqdaq spreading. The one and only manuscript which stated Kalindaqdaq is Lontar Pattapingang. Similar to other local literature, nobody knows the authors of Kalindaqdaq. Nowadays, people are free to creat, copy or modify it in all Mandaresse event where Kalindaqdaq is shown. ${ }^{9}$

Kalindaqdaq has important position in Mandarese. It reflects values, knowledge, norms and ethics that are extracted in local wisdom. Kalindaqdaq also plays its social role such as mediating the social interaction among Mandarese, educating and entertaining. The specific function will be adjusted based on its themes. And below are seven themes of Kalinndaqdaq ${ }^{10}$ : humor (Kalindaqdaq Pangino), satire (Kalindaqdaq Mattedze), social critics (Kalidaqdaq Pappakaningaq), education

${ }^{7}$ Suradi Yasil and Muhammad Darwi, Language Style on Kalindaqdaq Poem (Introduction of Stylistic tudy on Mandar Regional Literature, International Journal on Science and Research, Vol 6, Issue 9. (2017)

${ }^{8}$ Idham Khalik Bodi, Rukun Islam dalam Kalindaqdaq (The Five Pillars of Islam in Kalindaqdaq). Jurnal Sawerigading, Vol. 19, No. 2. (2013)

${ }^{9}$ Suradi Yasil dan Muhammad Darwis. Language Style on the Kalindaqdaq Poem (Introduction of Stylistic Study of Mandar Regional Literature). International Journal of Scienceand Research, Vol 6, Issue: 9. (2017),

${ }^{10}$ A.M. Sarbin Sjam, Bunga Rampai Kebudayaan Mandar dari Balanipa, (Polewali Mamasa: 1997). 
(Kalindaqdaq Pipatudzu), religion (Kalindaqdaq Masalah), patriotism (Kalindaqdaq Pettomuaneang) and romantic (Kalindaqdaq Tosipomongeq)

Paying close attention to those types of Kalindaqdaq, certainly there is a specific zone for each type. They have each scope such as where it is performed and who the audiences are. For instance, Kalindaqdaq Masaala is performed in religion rituals, Kalindaqdaq Tosipomonge is performed to tempt tomessawe ${ }^{11}$ in mappatamma ' ritual, or Kalindaqdaq Pettomuaneang can be listened at traditional self-defense performance as known as Pammacca. It shows that Kalindaqdaq is not only a way of expressing feeling and thought, but also it has been part of Mandarese rituals which is believed as prayer.

\section{FROM TEXT TO CONTEXT}

The terms such as text and context actually have been discussed by linguists, although they understood them in different ways. Some experts said that the text is inside of context; next, context involves situation and condition around that text production. ${ }^{12}$ Next, linguists like Halliday, Butt et.al, Bauman and Briggs believed that it is too complicated for defining what text and context are. The key point is that text and context cannot be considered as two different variables where one could influence another one as dependent and independent one (Zulkhaeriyah 2018) ${ }^{13}$.

A text is language performance either spoken or written. The length of text is not substantial; the important thing is that a text is a corresponding collection of meanings fitting to its context. It has two elements namely structure and texture. ${ }^{14}$ Structure is about the way that pieces of language in use will contain essential structural elements appropriate to its purpose and context. And texture is the way of meanings in the text fit coherently with each other. Object in the text could be independent, but the meaning of that object attaches to the context. Different people will understand the meaning and purpose of a text because they share context each other. It can be concluded that text defines context; and vice versa context defines text. ${ }^{15}$

It is too risk to define what context is. Definition sometimes limits the flexibility of object, whereas context needs flexibility so much. An allowable change might be considered occur from time to time. That is why experts did not give definition toward

\footnotetext{
${ }^{11}$ People who finish reciting Al-Quran; they ride a horse, and paraded around the village.

${ }^{12}$ Weisenrieder \& Fairclough, Critical Discourse Analysis: The Critical Study of Language, (USA: 1997)

${ }^{13}$ Zulkhaeriyah, The Discursive Interaction between Representative Man and Woman in Mappettu Ada Marriage Proposal in Buginese Society (A Semiotic Approach), Jurnal Adabiyah, Vol.18, No.1. (Makassar: 2018) 2003)

${ }^{14}$ David Butt et.al, Using Functional Grammar: An Explorer's Guide, Second Edition; (Sydney:

${ }^{15}$ Carlos Gershenson, Contextuality: A Philosophical Paradigm, with Application to Philosophy of Cognitive Science, Accessed from https://www.researchgate.net/publication/ on February, $11^{\text {st }} 2017$ at $8 \mathrm{am},(2002)$
} 
context clearly. Until today, they just describe a notion about that. Simply, context is seen as circumstances of text production and text reception including place, time, situation, people, social, cultural, and so on. The after question is where place; what time; how situation; who people; what cultural background does it mean? ${ }^{16}$ If the answer is the involved one, so the answer is not fair. A text which is produced today absolutely has relation to some texts which were produced a time ago. People as the context are not only the involved ones, but also people who do not act as the speaker and the listener at the time. In other words, the present-day context relates with the past and the future context, and it is unlimited. The context could be infinite, so that people need to find the most relevant one.

Objects or ideas in a text are not explicit completely. Some implicit things are also in. Here the context plays an important role in creating that implicit information. As the result, the context has an essential part to consider the meaning of that implicit information. Place, time, observers (men, animals, and systems), situation and culture give meaning to everything. It does not have a meaning by itself. And again, the responsibility of context is not about part of semantics. It is a philosophical case which is able to set up the semantic theories successfully. ${ }^{17}$

\section{Contextualization And Entextualization}

A shift from study of texts (structural text) to analysis of the emergence of texts in context is the urgent move in the establishment of performance approaches. The focus of experts had changed from a point of view toward context as conceived in normative, conventional and institutional terms. Much performance-oriented research has focused on the grounding of performance in situational context including contextualization and entextualization aspect of performance. This issue emerges because any verbal art forms are so risk to self-contained treatment, whereas they are not separable from their social and cultural context of production and reception.

Contextualization is a process which makes object in text being close with the reality. This process involves an active negotiation process among participants as the members of social interaction. In another word, the successful of context to contextualization process depends on that negotiation process. As instance, when a speaker says ' $I$ ', the speaker and his listener will negotiate in each own minds that ' $I$ ' refers to the reality of the speaker; although the reality of 'I' can refer to whoever in this world. Another example is the using of spatial deictic such as 'this', 'that', etc. When a speaker says 'this problem', it means that the problem that he talks about is near to the speaker, although he does not mention the spatial area of that problem. And

${ }^{16}$ Rabiatul Adawiah, Modalities Used By Indonesian and American In Political Debate Discourse, Jurnal Adabiyah, Vol. 17, No.1. (Makassar: 2017)

${ }^{17}$ Carlos Gershenson, Contextuality: A Philosophical Paradigm, with Application to Philosophy of Cognitive Science, Accessed from https://www.researchgate.net/publication/ on February, $11^{\text {st }} 2017$ at $8 \mathrm{am},(2002)$ 
to make the discussion of that problem running successfully, the audience should agree with the speaker related to what and where that problem is. ${ }^{18}$

The early explanation above describes that the text is inside of the context. The process of taken away that text from its context is called as decontextualization; meanwhile, the process of putting that text in another context is as recontextualization. And the sequence of both processes is termed as entextualization. In another word, it is about how text which was performed in the existed context before is transformed in another context. Of course, extextualization has connection with the performativity level of language use (Geeraerts 2014) ${ }^{19}$.

Entextualization is a basic process of power and authority. With a power, entextualizing agents are able to putting up the relationship between the original context and the textual product. Such strategies include how entextualizing agents choose that purpose context and measure the gaps between the original and the purpose context. While the gaps are the certain result of entextualization as an act of discursive displacement, in particular instances the gaps could be maximized and minimized. It means that to do entextualization including decontextualization and recontextualization is an act of control. The congruity between two contexts is not social or cultural given, while it is the result of human thinking. In doing entextualization, agent should have competence which may come from innate human ability, learned skill, special gift, power from one's position, and others. ${ }^{20}$

\section{Research Methodology}

This research used qualitative method as a way to report Mandarese life as an ethnic including its local wisdom, identity and cognitive characteristic by observing the contextualization and entextualization process on Kalindaqdaq performance. This research combined two approaches. The primary one is semiotic functional approach in doing content analysis on text, and the secondary one is ethnography approach in doing participant observation to support data of text analysis.

The objects of this research are some Kalindaqdaq Pettomuaneang texts collected by the researchers at Pammacca rituals in Polewali Mandar regencies as field of study. The researchers attended that rituals in 2016 and the researchers only gained four texts. Those all texts were recorded and they had been transcribed word by word. The analysis was started by identifying language features of each Kalindaqdaq text;

\footnotetext{
${ }^{18}$ Stanislaus Sandarupa, The Voice of a Child $\{"\}$ : Constructing a Moral Community through Retteng Poetic Argumentation in Toraja, Archipel-Etudes Interdisciplinaires Sur Le Monde Insulindien Journal (2016)

${ }^{19}$ Dirk Greeraerts, From structure to context. Decontextualization and recontextualization in the history of linguistics, accessed from http://www.ling.art.kuleuven.be on February, $12^{\text {nd }} 2017$ at 2 pm, (Belgia: 2014)

${ }^{20}$ Richard Bauman \& Charles L. Briggs, Poetics and Performance as Critical Perspectives on Language and Social Life, Annual Review of Anthropology, Vol. 19, 1990, accessed http://www.jstor.org/ on January, $14^{\text {th }} 2017$ at 8 am, p.77 (1990)
} 
interpreting the purpose and the meaning of words and features; associating the result of interpretations with the data of participant observation; and synthesizing conclusion.

\section{Discussion}

\section{Contextualization of Mandaresse Patriotism Concept in Kalindaqdaq Pettomuaneang}

Kalindaqdaq Pettomuaneang firstly was conveyed only to man. Its content could be understood as inspiration for Mandarese man. A man who was able to perform philosophical values of Kalindaqdaq Pettomuaneang in daily life was seen as a model of patriotism based on Mandarese context point of view. Later on, that objective of Kalindaqdaq Pettomuaneang changed following historical event last time. For several eras, Mandarese was led by women such as $\mathrm{Hj}$. Andi Depu. After that, Kalindaqdaq Pettomuaneang has been conveyed to woman too. Its philosophical values are understood in more general thinking. It becomes a momentum of the equality of man and woman in Mandarese.

The rising of Kalindaqdaq Pettomuaneang performance in Mandarese context was influenced by political situation at the time. Mandarese codices noted that there were some wars and conflict which threatened the unity of Mandarese. Some conflicts were internal issue among some of fourteen kingdoms as the members of Mandarese coalescence; and others were external conflicts among other ethnics around Mandarese and also colonialist. The set of conflict was too complicated; so that it was urgent having qualified figure that was able to lead and solve problems at the time. The characteristics of qualified leader based on Mandarese point of view were described in Kalindaqdaq Pettomuaneang.

As an oral literature, Kalindaqdaq is free to be re-used anytime and anywhere in all events. The same data could be found by some reseachers, although they conducted research in different time or different places. It indicates that Kalindaqdaq texts are owned by all Mandaresse society. Kalindaqdaq also can be modified. The previous and recent studies found that some Kalindaqdaq texts do not match with the original charateristic. It's characteristics are 1) a stanza of Kalindaqdaq has four lines; 2 ) the first line consists of 8 syllables, the second line consists of 7 syllables, the third line consists of 5 syllable, and the last line consists of 7 syllables. ${ }^{21}$ Meanwhile, the previous and recent researchers found that Kalindaqdaq performers did not obey those rules in particularly numbers of syllable.

Based on the result of contextualization analysis, here are the patriotism characteristics of Mandaresse:

\section{a. Sincerity}

The first characteristic that an ideal man should have is the sincerity. This essence is portrayed through Kalindaqdaq Pettomuaneang text. Here is the first text:

(Datum 1)

${ }^{21}$ Idham Khalik Bodi, Rukun Islam dalam Kalindaqdaq (The Five Pillars of Islam in Kalindaqdaq). Jurnal Sawerigading, Vol. 19, No. 2. (2013) 


\author{
Inditia tomuane \\ Bannang pute sarana \\ Meloq dicinggaq \\ Meloq dilango-lango \\ (This is a patriot \\ White yarn is his/her sense \\ Ready to be colored \\ Ready to be given dye)
}

The text above directly describes about a patriot or an ideal leader, although the explanation of its characteristics is shown discursively. The text is begun by spatial deictic 'inditia' which refers a close relationship between the text performer and that patriot. In other words, the figure that was considered having patriotism was obvious at the time. Historical codices also noted that the kings of Mandarese were known as high patriotism and brave figure. As the King of Arrayangang Mandar, most of them were known as rebel by colonial at the time.

The second line of text used metaphor by comparing the white yarn and sense of tomuane. The white yarn refers to the sincerity and the purity of tomuane's heart. Next, the third and the fourth line are begun with meloq that means the readiness. Like the white yarn which is ready to be colored with any colors, the sense of tomuane that is pure is also ready actualized in any ways for the sake of the societies. And in the worst situation, tomuane should be ready to die in struggling for societies as the white yarn which is ready to be given red color. In conclusion, in Mandarese point of view an ideal leader should acquiesce in prioritizing his/her societies rather than his/her personal interest.

Nurhayati (2014) also presented this datum in her research. In several parts, the explanation above has similarity with that previous study. These datum was interpreted as spirit of patriotism which shows the purity and readiness to face all obstacles ${ }^{22}$. Meanwhile, Yasil and Darwis (2017) also found humble as image of Mandaresse from analysing other two stanzas of Kalindaqdaq. ${ }^{23}$ Althoght it is explained shortly by Yasil and Darwis, 'humble' and 'sincerity' are interrelated. A leader should be sincerity, humble, and not arrogant by seeing his self in line with other societies.

\title{
b. Consistent
}

The second characteristic of tomuane is consistent for every word he/she has said. What to do is what to say, and vice versa. The text below shows that characteristic:

\section{(Datum 2)}

\footnotetext{
${ }^{22}$ Nurhayati, Patriotisme dalam Kalindaqdaq Mandar. Prosiding Seminar Nasional Bahasa dan Sastra. (2014)

${ }^{23}$ Suradi Yasil and Muhammad Darwis, Language Style on Kalindaqdaq Poem (Introduction of Stylistic tudy on Mandar Regional Literature, International Journal on Science and Research, Vol 6, Issue 9. (2017)
} 


\author{
Mua' purami dipau \\ Purami dipoloa \\ Da leqba tia \\ Soroq tammassaqbi \\ (When it has been talked \\ Has been mentioned \\ Ought not to \\ Disappear without any trace)
}

The meaning of this Kalindaqdaq text above can be interpreted easily from its text. This Kalindaqdaq educates Mandarese to have responsibility for every word mentioned from the mouth. The indication of that focus is parallelism used in the first and the second line. The parallelism of speech events pau and poloa certainly has intention. An utterance is not only about the letters and words combination, but it also reflects the speaker's self and his/her relationship with societies and God. In nowadays context, people including politician are easily to disavow their campaign promise after selected in general election and so on. Firstly, they were so enthusiastic persuading people by promising everything. Then when they were elected, they just forgot. The did not realize that disavowing a promise not only breaks the relation between speaker and the listener, but also it breaks his/her relation with the God.

The last line also describes the contextulization cues. Literally, saqbiq or 'trace' means a mark, an object, or a sign showing what has existed or happened. When it is interpreted related to the previous text, saqbiq reveals to the proof of everything talked by mouth. Word which represents the language has interconnection with the object in reality. A speaker should be responsible to establish facts of his/her words. So when a speaker talks about justice, he/she has responsibility to construct the justice as he/she means being object in reality. In conclusion, the content and the purpose of speech event have to be consecutive with its realization. As a good speaker, everyone should have high commitment toward the proposition of language used, and be wise in every speech event.

The same datum was used by Nurhayati (2014) to represented knight spirit of Mandaresse patriotism. Quoted by Kamus Besar Bahasa Indonesia, knight means kind, honest and brave. ${ }^{24}$ Yasil and Darwis (2017) also found knight as image of Mandaresse, but they described it in different text. Altough these characteristics has relation, consistent is the most correct word to represent that patriotism values in this text. Pau and loa has same meaning namely 'say'; the use of pau and loa in the same text indicated that every said/spoken things are important. Saying something is not only about producing word, but also it is about relation with interlocutors and others.

${ }^{24}$ Nurhayati, Patriotisme dalam Kalindaqdaq Mandar. Prosiding Seminar Nasional Bahasa dan Sastra. (2014) 


\section{c. Bravery and Firmness}

The third Kalindaqdaq Pettomuaneang illustrates the bravery and the firmness as the patriot's characteristics. Here the text is:
(Datum 3)
Namanetteaq lipaq
Sureq disigayanni
Puccana ceraq
Birinna mata gayang
(I am going to weave sarong
Its motif is the mutual stabbing
Centre of motif is blood
Its edge is kris edge)

Gayang is a term for traditional weapon of Mandarese. It looks like a kris or knife with small size. Mandarese does not treat gayang as inanimate object. It is regarded as heirloom object that needs food as living object. Their belief drives their self to do certain behavior, although it is out of a normal human thinking. Another extreme belief, it is taboo to put it back in its place (guma) before touching human blood. So, the implication is a person should be wise in showing gayang in public. The use of gayang in patriotism Kalindaqdaq has certain reason. It reflects bravery and firmness controlled by carefulness as absolute characteristic of an ideal leader.

This stanza was interpreted differently by Nurhayati. Sureq disigayanni (mutual stabbing) is undestood as indication of unity spirit in patriotism. ${ }^{25}$ It can be assumed that sarong is made by uniting many threads. The problems are line 3-4 do not have any corelation with that interpretation. In Mandaresse context, ceraq (blood) exactly is associated to conflict rather than unity. So, there is contradictive in the previous research's explanation.

The next Kalindaqdaq uses symbol of weapon too. Following its name 'Kalindaqdaq Pettomuaneang', it is natural for the writer of Kalindaqdaq to use Mandarese King's properties such gayang, kowiq, etc. Here is the next Kalindaqdaq:
(Datum 4)
Usappeangi kowiqu
Muaq diang caiqmu
Mecawa pao
Annaq uambeimi
(I hang up my knife
If you have anger
When you laugh
Then I take it back)

${ }^{25}$ Nurhayati, Patriotisme dalam Kalindaqdaq Mandar. Prosiding Seminar Nasional Bahasa dan Sastra. (2014)

\section{2}


As it can be seen above, kowiq is stated metaphorically in the first line. It represents the ego. Kowiq which is translated in English as knife has two contradictive sides. It can be used to pare an apple, and it also can be used to kill someone. Seems like knife, ego has contradictive sides too. It can drive someone to protect his/her pride and hurt his/herself or other people all at once. But the comparison is not only about those contradictive sides because everything in this universe has it. The main point is that knife and ego is something sharp. Similar to knife, ego is able to create and add injures. Knife will injure physically; meanwhile, ego can injure psychologically.

The researchers think that ego is the interpretation of kowiq. It is supported by the last line 'Annaq Uambeimi' (Then I take it back). The correlation of the first and the last line describes that the ego is something urgent to be had, like a Mandarese man should kowiq or gayang everywhere. Next in Mandarese, ego is urgent to be defensed as a part of siriq and lokkoq (Idham 2007) ${ }^{26}$. In this part, ego as part of siriq and lokkoq could be a controller to internalize malaqbiq, a concept of being a noble person based on Mandarese point of view. In more specific, a malaqbiq leader is someone who is able to execute human power with full of affection. He/she has strong affective domain such as firmness, morality and responsibility which completed by cognitive and motoric domain. And once again, ego here has role as the controller of his/her commitment to realize that vision. In conlusion, following the explanation above this Kalindaqdaq illustrates calm characteristic in problem solving. A person with patriotism soul never uses violence as result of over ego in clearing up any problems.

Following that explanation, both Kalindaqdaq texts also confirm what Yasil and Darwis have concluded namely 'obey the laws/rules' as one image of Mandaresse (Yasil and Darwis 2017) ${ }^{27}$. In fact, many Mandaresse figures showed their firmness in daily life. One of them is Baharuddin Lopa who is known as honest and firm person. When he worked as law enforcer in his life, he obeyed every laws and rules without considering of his interest. He is successful implementing siriq and lokkoq in his behaviour.

\section{Entextualization Process of Kalindaqdaq Pettomuaneang Performance}

Entextualization in Kalindaqdaq Pettomuaneang refers to the process of the speaker, the performer or the entextualization agent in extracting text from its original text (decontextualization) and expressing it again in Kalindaqdaq performance (recontextualization). The first description is about the entextualization from manetteq (weaving) context into patriotism context. There are two texts which used this original and purpose context and here are the texts:

\footnotetext{
${ }^{26}$ Idham, Soialisasi Nilai Budaya Mandar, Jurnal Al-Qalam, Vol 8, no. 20. (2007)

${ }^{27}$ Suradi Yasil and Muhammad Darwis, Language Style on Kalindaqdaq Poem (Introduction of Stylistic tudy on Mandar Regional Literature, International Journal on Science and Research, Vol 6, Issue 9. (2017)
} 


\author{
Inditia tomuane \\ Bannang pute sarana \\ Meloq dicinggaq \\ Meloq dilango-lango \\ (This is a patriot \\ White yarn is his/her sense \\ Ready to be colored \\ Ready to be given dye) \\ Namanetteaq lipaq \\ Sureq disigayanni \\ Puccana ceraq \\ Birinna mata gayang \\ (I am going to weave sarong \\ Its motif is the mutual stabbing \\ Head of motif is blood \\ Its edge is kris edge)
}

It can be seen from both texts above, some terms in manetteq context are brought into patriotism context such as manetteq (weave), lipaq (sarong), banning pute (white yarn), lango-lango (dye), sureq (motif), and pucca (head of motif). Those terms are decontextualized, or they are extracted far from weaving context. And after that they are expressed again in patriotism as its new context.

There are two main implications from this entextualization. Firstly, Mandarese notice that the leadership process is same as the weaving process. Manetteq or weaving is a series of steps to turn silk into sarong started by spinning silk into yarn, coloring that yarn, and stringing up that colored yarn to be silk sarong. Weaving a silk sarong need around two months, so its process takes a long time enough. Being a good leader needs that process also. It needs patient and tenacity. To build a good govern the leader certainly will face many challenges, and it is not a short and simple case. In short, leadership in Mandarese point of view is as same as weaving sarong (manetteq lipaq saqbe). Not only be carefulness, a good leader should be creative.

The second implication is about the result oriented. The product of manetteq is termed as lipaq saqbeq (silk sarong). For Mandarese, lipaq saqbe has essential value rather than just as part of dress. It plays social role, and it has specific regulation related to its using. Motif, color, and the way of using are classified based on the context. That is why the social class, marital status and kinds of cultural event are considered to choose motif, color and the way of using. Related to entextualization, the word lipaq is taken from manetteq context and told it again in Kalindaqdaq Pettomuaneang. Mandarese notice patriotism characteristic as the prestige result of leadership process, and it is similar to lipaq saqbe as the result of manetteq. Lipaq Saqbe can deliver selfconfidence to its user, as patriotism can give a special pride to the noble one.

The next issue is about (dis)identification as one result of entextualization that found in Kalindaaqdaq Pettomuaneang. Symbols used in Kalindaqdaq absolutely 
reflect the identity of Mandarese. For instance, mostly Kalindaqdaq Pettomuaneang texts use weapon terms such as kowiq and gayang. If they are interpreted simply, people could judge Mandarese as inflexible and gruff ones. And after passing through entextualization, meaning making of those symbol changes following the purpose context. The reflected identity from interpreting weapon symbols simply in its original context has been (dis)identified in the purpose context. By presenting manetteq context, those symbols are interpreted out of its original context. They do not reflect something sharp and injuring anymore. The result of this entextualization is (dis)identification to be leadership with firmness and flabbiness all at once.

Lastly, it is interesting to discuss the consciousness in contextualizing and entextulizing Klaindaqdaq text which represents cognitive characteristic of Mandarese. It consists of a divergence between a personal context and other kinds of context. In doing contextualization and entextualization, person needs consciousness to integrate his/her personal context, interlocutor's context, original context and purpose context. And not all people are able to do this, although most people face multiple contexts. By examining the Kalindaqdaq Pettomuaneang, it can be seen that the writer of Kalindaqdaq as the representative of Mandarese and the entextualization agent has been successful to construct attractively some complicated contexts including personal, patriotism, historical, manetteq, weapon, and other in Pettomuaneang text by minimalizing gaps among those contexts. So the researchers conclude that Mandarese is an ethnic with high cognitive characteristic. Because of to do contextualization and entextualization, people should have specific competence in language and logic as innate human ability and learned skill.

\section{E. Concluding Remarks}

Conducting cultural studies is not a simple matter. Cultural object is unlimited, so the methodology including approach, technique, and research duration should meet the appropriateness in quality and quantity. Sometimes the researcher has arranged a research design, then it changes after facing the field of research. This is a specific challenge for researcher in using qualitative method. Another limitation of this research is the source of Data. There is no valid information about the first author of Kalindaqdaq. The available references are also limited. That is why the researchers suggest the next research to find and interview as many as possible experts.

The challenge does not mean to be such a big obstacle. Cultural studies should continue to explore the rich local wisdoms in Indonesia, and in Mandarese particularly. As an example shown in this study, people can learn about the patriotism from local text as a reference such as Kalindaqdaq and local figures as role models. The researchers also do hope that there will be more researches related to other themes of Kalindaqdaq or other cultures in Indonesia, and the researchers believe that it certainly is able to present significance theoretically and practically. 


\section{BIBLIOGRAPHY}

Adawiah, Rabiatul. 2018. "Modalities Used By Indonesian and American In Political Debate Discourse (A Comparative Study)." Jurnal Adabiyah. https://doi.org/10.24252/jad.v17i1i1a1.

Badan Pusat Statistika Provinsi Sulawesi Barat. 2016. "Jumlah Penduduk Menurut Kabupaten/Kota, 2010-2015.” http://sulbar.bps.go.id.

Bauman, R. 1990. "Poetics And Performance As Critical Perspectives On Language And Social Life." Annual Review of Anthropology. https://doi.org/10.1146/annurev.anthro.19.1.59.

Bodi, Idham Khalik. 2013. "Rukun Islam Dalam Kalindaqdaq (The Five Pillars of Islam in Kalindaqdaq)." Jurnal Awerigading 19 (2).

Butt, David, Rhondda Fahey, Susan Feez, Sue Spinks, and Colin Yallop. 2003. "Using Functional Grammar." Using Functional Grammar: An Explorer's Guide. https://doi.org/10.1108/10662240410517434.

Geeraerts, Dirk. 2014. "From Structure to Context. Decontextualization and Recontextualization in the History of Linguistics." Plenary Lecture at the 35th Annual Meeting of the Department of Linguistics, May 9-10, 2014, School of Philology, Aristotle University of Thessaloniki, Thessaloniki, Greece. http://wwwling.arts.kuleuven.be/qlvl/prints/Geeraerts_2014pres_structure_conte xt_de_re_contextualisation.pdf\%0Ahttps://lirias.kuleuven.be/handle/123456789/ 460396.

Gershenson, Carlos. 2002. "Contextuality: A Philosophical Paradigm, with Applications to Philosophy of Cognitive Science." POCS Essay, COGS.

Idham. 2007. "Sosialisasi Nilai Budaya Mandar." Jurnal Al-Qalam 8 (20).

Kasitowati, Rarasrum Dyah. 2011. "Sandeq Dan Roppoq.” Sabda 6 (1): 63-68.

Mattulada, Andi. 1982. "South Sulawesi, Its Etnicity and Way of Life." Southeast Asian Studies 20 (1): 4-12. https://doi.org/10.7454/ai.v0i48.3279.

Nurhayati. 2014. "Patriotisme Dalam Kalindaqdaq Mandar." Prosiding Seminar Nasional Bahasa Dan Astra.

Sandarupa, Stanislaus. 2016. "The Voice of a Child\{" $\}$ : Constructing a Moral Community through Retteng Poetic Argumentation in Toraja." Archipel-Etudes Interdisciplinaires Sur le Monde Insulindien. https://doi.org/10.4000/archipel.316.

Spradley, James P. 1980. "Doing Participation Observation." In Participant Observation. 
Weissenrieder, Maureen, and Norman Fairclough. 1997. Critical Discourse Analysis: The Critical Study of Language. The Modern Language Journal. https://doi.org/10.2307/329335.

Yasil, Suradi, and Muhammad Darwis. 2017. "Language Style on the Kalindaqdaq Poem (Introduction of Stylistics Study of Mandar Regional Literature)." International Journal of Science and Research 6 (9).

Zulkhaeriyah, Zulkhaeriyah. 2018. "The Discursive Interaction Between Representative Man And Woman In Mappettu Ada Marriage Proposal In Buginese Society (A Semiotic Approach)." Jurnal Adabiyah. https://doi.org/10.24252/jad.v17i118i1a2. 


\section{Guidelines}

\section{Submission of Article}

urnal Adabiyah welcomes the articles submission with the main themes on Humanities and Islamic Studies with the emphasis on interdisciplinary and intertextuality approach. Adabiyah is thematicly published twice in a year. ie the theme of the humanities in June and the Islamic Study in December.

Themes related to Islamic Studies are textual studies, scriptural traditions, Islamic law, and theology; and those related to Humanities are language, literature, history, and culture. This scholarly journal Guarantees that the editor decision based on the peer review results will not exceed 30 days from the paper submission date.

Authors are invited to read our archives; to find the relevant topics for the journal, and to submit complete unpublished scientific researches, which are not under review in any other conferences or academic journal.

\section{PUBLICATION ETHIC}

Publication Ethic and Malpractice Statement

Jurnal Adabiyah is a peer-reviewed journal, published twice a year by the Faculty of Adab and Humaniora, Alauddin State Islamic University of Makassar Indonesia. It is available online as open access sources as well as in print. This statement clarifies ethical behaviour of all parties involved in the act of publishing an article in this journal, including the author, the editor-in-chief, the Editorial Board, the reviewers, and the publisher. This statement is based on COPE's Best Practice Guidelines for Journal Editors.

Ethical Guideline for Journal Publication

The publication of an article in Jurnal Adabiyah, is an essential building block in the development of a coherent and respected network of knowledge. It is a direct reflection of the quality of the work of the authors and the institutions that support them. Peer-reviewed articles support and embody the scientific methods. It is therefore important to agree upon standards of expected ethical behavior for all parties involved in the act of publishing: the author, the editor, the reviewer, the publisher, and the society. As the publisher of Jurnal Adabiyah, the Faculty of Adab and Humaniora takes its duties of guardianship over all stages of publishing seriously and it recognizes its ethical and other responsibilities. The Faculty of Adab and Humaniora committed to ensuring that advertising, reprint or other commercial revenue has no impact or influence on editorial decisions.

\section{Publication Decisions}

The editors of Jurnal Adabiyah is responsible for deciding which articles submitted to the journal should be published. The validation of the work in question and its importance to researchers and readers must always drive such decisions. The editors may be guided by the policies of the journal's editorial board and constrained by such legal requirements as shall then be in force regarding libel, copyright infringement, and plagiarism. The editors may confer with other editors or reviewers in making their decisions.

\section{Plagiarism Screening}

It is basically author's duty to only submit a manuscript that is free from plagiarism and academically malpractices. The editor, however, will check all submitted papers through Turnitin.

\section{Fair Play}

An editor at any time evaluates manuscripts for their intellectual content without regard to race, gender, sexual orientation, religious belief, ethnic origin, citizenship, or political philosophy of the authors. 


\section{Confidentiality}

The editors and any editorial staff must not disclose any information about a submitted manuscript to anyone other than the corresponding author, reviewers, potential reviewers, other editorial advisers, and the publisher, as appropriate.

\section{Disclosure and Conflicts of Interest}

Unpublished materials disclosed in a submitted manuscript must not be used in editors' own research without the express written consent of the author.

\section{DUTIES OF AUTHORS}

\section{Reporting Standards}

Authors of reports of original research should present an accurate account of the work performed as well as an objective discussion of its significance. Underlying data should be represented accurately in the paper. A paper should contain sufficient detail and references to permit others to replicate the work. Fraudulent or knowingly inaccurate statements constitute unethical behaviour and are unacceptable.

\section{Originality and Plagiarism}

The authors should ensure that they have written entirely original works, and if the authors have used the work and/or words of others that this has been appropriately cited or quoted.

\section{Multiple, Redundant, or Concurrent Publication}

An author should not in general publish manuscripts describing essentially the same research in more than one journal or primary publication. Submitting the same manuscript to more than one journal concurrently constitutes unethical publishing behaviour and is unacceptable.

\section{Acknowledgement of Sources}

Proper acknowledgment of the work of others must always be given. Authors should cite publications that have been influential in determining the nature of the reported work.

\section{Authorship of the Paper}

Authorship should be limited to those who have made a significant contribution to the conception, design, execution, or interpretation of the reported research. All those who have made significant contributions should be listed as co-authors. Where there are others who have participated in certain substantive aspects of the research project, they should be acknowledged or listed as contributors. The corresponding author should ensure that all appropriate co-authors and no inappropriate co-authors are included on the paper, and that all co-authors have seen and approved the final version of the paper and have agreed to its submission for publication.

\section{Disclosure and Conflicts of Interest}

All authors should disclose in their manuscript any financial or other substantive conflict of interest that might be construed to influence the results or interpretation of their manuscript. All sources of financial support for the project should be disclosed.

\section{Fundamental errors in Published Works}

When an author discovers a significant error or inaccuracy in his/her own published work, it is the author's obligation to promptly notify the journal editor or publisher and cooperate with the editor to retract or correct the paper.

\section{PLAGIARISMIF}

It is basically author's duty to only submit a manuscript that is free from plagiarism and academically malpractices. The editor, however, will check all submitted papers through Turnitin. 


\section{AUTHOR GUIDELINES}

\section{Guidelines for online submission:}

1. Author should first register as Author to the website of Jurnal Adabiyah. Click the menu "register" to register as an author.

2. Once after the author is registered, please login to the website of Jurnal Adabiyah and submit the article through online submission (with the stat us of active submissions).

3. The article should follow the standard template of Jurnal Adabiyah provided in the website.

4. The citation and bibliography should follow the Turabian citation style.

5. Author is restricted not to send his/her article to another journal before having confirmation from the editorial team (approximately 4 weeks right after the article submitted).

6. Author should follow editorial decisions and recommendations related to the article completion. All reviews and assessements will be informed through online submission.

Article submitted to Jurnal Adabiyah editorial board must follow these guidelines:

1. Article should be based on the scientific research in the field humanities and Islamic studies;

2. Article must be an original work and has not been previously published;

3. Article should be written in Arabic or English languages;

4. Article must be typed in one-half spaced on A4-paper size;

5. Article's length is about $6,000-10,000$ words;

6. All submission must include a 150-250 word abstract;

7. Abstract should be written in 3 languages; Arabic, English, and Bahasa;

8. Full name(s) of the author(s) must be stated, along with his/her/their institution and complete address;

9. All submission should be in OpenOffice, Microsoft Word, RTF, or WordPerfect document file format;

10. Bibliographical reference must be noted in footnote and bibliography according to Jurnal Adabiyah style. In addition, it is suggested for author(s) to use reference manager tools such as 30 MENDELEY or 2 otero

When a source is cited for the first time, full information is provided: full name(s) of author(s), title of the source in italic, place of publication, publishing company, date of publication, and the precise page that is cited. For the following citations of the same source, list the author's last name, two or three words of the title, and the specific page number(s). The word ibid., op.cit., and loc.cit. are may not be used any more.

\section{Example in footnotes:}

${ }^{1}$ Mircea Eliade (ed.), The Encyclopedia of Religion, vol. 8 (New York: Simon and Schuster, 1995), h. 18.

${ }^{2}$ Norman Daniel, Islam and the West (Oxford: One World Publications, 1991), h. 190.

${ }^{3}$ Syeikh Ja'far Subhānī, Mafăhim Al-Qur'ān (Beirut: Mu'assasah Al-Tarikh Al-'Arabī, 2010)., Juz 5, h. 231. 
${ }^{4}$ Syeikh Ja'far Subhānī, Mafăhim Al-Qur'ān, h. 8-9.

\section{Example in bibliography:}

Subhānī, Syeikh Ja'far. Mafāhim Al-Qur'ān. Beirut: Mu'assasah Al-Tarikh Al-'Arabī, 2010.

Eliade, Mircea (ed.). The Encyclopedia of Religion, vol. 8. New York: Simon and Schuster, 1995.

Daniel, Norman. Islam and the West. Oxford: One World Publications, 1991.

Shihab, Muhammad Quraish. Sunnah-Syiah Bergandengan Tangan: Mungkinkah? Kajian Atas Konsep Ajaran Dan Pemikiran. Cet. III. Jakarta: Lentera Hati, 2007.

Detail informations of the footnotes:

1. Holy book

Al-Qur'ân, Al-Baqarah/2: 185.

Perjanjian Baru, Mrk. 2: 18.

2. Qur'anic translation

${ }^{1}$ Departemen Agama RI, al-Qur'an dan Terjemahannya (Jakarta: Darus Sunnah, 2005), h. 55.

3. Book

${ }^{1}$ Muḥammad 'Ajjaj al-Khațib, Ușl al-Hadith: 'Ulumuh wa Mușțalaḥuh (Beirut: Dâr al-Fikr, 1989), h. 57.

4. Translation Books

${ }^{1}$ Toshihiko Izutsu, Relasi Tuhan dan Manusia: Pendekatan Semantik terhadap al-Qur'an, terj. Agus Fahri Husein dkk (Yogyakarta: Tiara Wacana, 2003), h. 14.

5. Voluminous book

${ }^{1}$ Muḥammad al-Ṭâhir b. 'Ashur, al-Tạnn̄̄r wa al-Tanwīr, Vol. 25 (Tunisia: Dâr al-Suhûn, 2009), h. 76.

${ }^{1}$ Muḥammad b. Ismā‘īl al-Bukharī, al-Jami` al-Ṣahịḥ, Vol. 2 (Beirut: Dar al-Kutub al-‘Ilmìyah, 1999), h. 77.

6. Article in book

${ }^{1}$ Sahiron Syamsuddin, "Metode Intratekstualitas Muhammad Shahrur dalam Penafsiran al-Qur'an" dalam Abdul Mustaqim dan Sahiron Syamsuddin (eds.), Studi al-Qur'an Kontemporer: Wacana Baru Berbagai Metodologi Tafsir (Yogyakarta: Tiara Wacana, 2002), h. 139.

7. Article in encyclopaedia

${ }^{1}$ M. Th. Houtsma, "Kufr" dalam A. J. Wensinck, at al. (ed.), First Encyclopaedia of Islam, Vol. 6 (Leiden: E.J. Brill, 1987), h. 244.

8. Article in journal

${ }^{1}$ Muhammad Adlin Sila, "The Festivity of Maulid Nabi in Cikoang, South Sulawesi: Between Remembering and Exaggerating the Spirit of Prophet", Studia Islamika 8, no. 3 (2001): h. 9.

9. Article in mass media

${ }^{1}$ Masdar F. Mas'udi, "Hubungan Agama dan Negara", Kompas, 7 Agustus 2002. 
10. Article in Internet

${ }^{1}$ Muhammad Shahrūr, "Reading the Religious Teks: a New Approach" dalam http://www.shahrour.org/25 Februari 2010/diakses 5 Juni 2010.

11. Thesis or dissertation

${ }^{1}$ Syahruddin Usman, "KinerjaGuru Penddikan Agama Islam pada SMAN dan SMKN Kota Makassar”, Disertasi (Makassar: PPs UIN Alauddin, 2010), h. 200.

\section{COPYRIGHT NOTICE}

Authors who publish with this journal agree to the following terms:

1) Authors retain copyright and grant the journal right of first publication with the work simultaneously licensed under a Creative Commons Attribution License that allows others to share the work with an acknowledgement of the work's authorship and initial publication in this journal.

2) Authors are able to enter into separate, additional contractual arrangements for the non-exclusive distribution of the journal's published version of the work (e.g., post it to an institutional repository or publish it in a book), with an acknowledgement of its initial publication in this journal.

3)Authors are permitted and encouraged to post their work online (e.g., in institutional repositories or on their website) prior to and during the submission process, as it can lead to productive exchanges, as well as earlier and greater citation of published work (See The Effect of Open Access). 